\title{
Phenomenal Bombardment of Antibiotic in Poultry: Contemplating the Environmental Repercussions
}

\author{
Muthu Manikandan ${ }^{1,+}$, Sechul Chun ${ }^{1,+}{ }^{\mathbb{D}}$, Zakayo Kazibwe ${ }^{1} \mathbb{C}$, Judy Gopal $\left.{ }^{1} \mathbb{(}\right)$, \\ Udai Bhan Singh ${ }^{2}$ (i) and Jae-Wook Oh ${ }^{3, *(1)}$ \\ 1 Department of Environmental Health Sciences, Konkuk University, Seoul 143-701, Korea; \\ bhagatmani@gmail.com (M.M.); scchun@konkuk.ac.kr (S.C.); kajazacorp@gmail.com (Z.K.); \\ jejudy777@gmail.com (J.G.) \\ 2 Plant-Microbe Interaction \& Rhizosphere Biology LabICAR-National Bureau of Agriculturally Important \\ Microorganisms, Kushmaur, Mau Nath Bhanjan 275103, Uttar Pradesh, India; udaiars.nbaim@gmail.com \\ 3 Department of Stem Cell and Regenerative Biotechnology, Konkuk University, Seoul 143-701, Korea \\ * Correspondence: ohjw@konkuk.ac.kr; Tel.: +82-822-450-3727 \\ + Co-first authors, both authors have contributed equally towards the manuscript.
}

Received: 28 May 2020; Accepted: 8 July 2020; Published: 14 July 2020

\begin{abstract}
Antibiotics have constantly been added at an unprecedented rate in order to enhance poultry meat production. Such antibiotics impose a negative impact on human health directly through meat and egg consumption. On the other hand, they also affect humans indirectly by affecting the normal key microbial processes in the agricultural environments, when used as poultry compost. For many years, farmers have been turning poultry litter into compost for agricultural use. Very few studies have addressed the fate of the unmetabolized antibiotic residues in poultry litter that could potentially affect microbial communities when used as poultry compost. We have also questioned the fate of residual antibiotic in poultry waste which may create possible negative environmental pressure on microbial communities that are involved in microbial mediated poultry litter composting processes. The incorporation of antibiotic degrading environmental isolates in poultry litter at the initial stage of composting in order to accelerate the process is addressed in this review as a future perspective.
\end{abstract}

Keywords: poultry; composting; microorganisms; antibiotics; degradation; environment; toxicity

\section{Introduction}

The poultry industry is a valuable resource for meeting the protein needs of mankind through meat and egg supply. According to the Food and Agricultural Organization (FAO) report 2018 [1], poultry industry is one of the largest contributors amidst the global meat market with an estimated quantity of about 122.5 million tons. The increasing demand as evidenced in the past, signifies the vital role of poultry products. Therefore, the United States Food and Drug Administration approved the use of antibiotics as animal feed additives without veterinary prescription from 1951 in order to meet the rising demand [2]. European Union had ( $\sim 50$ years before) given the green signal for the unrestricted usage of any antibiotic as growth promoters [3]. Undoubtedly, this has accelerated meat and egg production to meet the rising human needs. On the other hand, this has also led to an alarming increase in the usage of a large number of antibiotics which in turn have affected human beings either directly through consumable poultry products or indirectly through destroying the beneficial microbial population that aid in agriculture. As it is well known, poultry litter is turned into poultry compost and used for enriching the agricultural environments.

It has been estimated that 1000 mature layer chickens approximately excrete $120 \mathrm{~kg}$ excreta/day and meat chickens: $80 \mathrm{~kg} /$ day, turkeys: $200-300 \mathrm{~kg} /$ day and ducks, $150 \mathrm{~kg} /$ day [4-6]. Although 
the poultry litter, as such, contains enormous nutrient content, the manure cannot be used directly because it does not support plant growth significantly when used as such without prior pretreatment. This is owing to the presence of high (60-80\%) organic nitrogen content (as protein and urea) [7]. This nitrogen cannot be assimilated by plants. Furthermore, ammonia $(\sim 40-90 \%)$ is constantly being formed from the poultry litter for a period of one year and such an accumulation causes acidification of soil substrates and vital cation $\left(\mathrm{K}^{+}\right.$and $\mathrm{Mg}^{2+}$ ) displacement that cause chlorosis of leaves and growth suppression $[8,9]$.

Composting of organic wastes, in general, is considered as an oxidative process mediated by bioentities via biomineralization and partial humification of the organic matter yielding a stabilized final product with certain humic properties and without phytotoxicity and pathogens [10]. Therefore, the poultry litter should be composted for a long time to release its maximum plant growth promoting potential. This generally relies on factors like water content, bedding materials (i.e., straw, wood shavings or rice hulls as is typical in meat bird housing) and the microbial population [11]. Sweeten (1988) had achieved poultry litter composting process in 4-6 weeks to obtain a minimum-quality-stabilized material [12]. Further, improvements had been made in poultry litter composting process by the addition of various amendments that includes two natural zeolites, clay, coconut coir. $\mathrm{CaCl}_{2}, \mathrm{CaSO}_{4}, \mathrm{MgCl}_{2}$, $\mathrm{MgSO}_{4}$ and $\mathrm{Al}_{2}\left(\mathrm{SO}_{4}\right)^{3-}$ have been added in order to reduce the composting period between days 49 to 56 for obtaining the stabilized compost containing mineralized ammonia [13].

Although the influence of many factors in poultry composting process have been studied [14-19], the role of one of the vital factors, i.e., antibiotics (which is supposed to be a determinable factor for the bio-entities that perform the biooxidative process during compost maturity), had completely been ignored. The presence of antibiotics is no longer in trace quantities but has become alarmingly high, since an enormous amount of antibiotics with broad spectrum of activity have been used in poultry. Therefore, this current review puts on journal record the significance of poultry manure and the role of antibiotics used in poultry and their impact on the microbial system that performs various biooxidation processes. While the effect of antibiotics and their pharmacokinetics in poultry meat and their system has been studied, almost no validated reports exist with respect to antibiotic residues in poultry litter and poultry compost and their subsequent movement in agricultural soils and crops and animals and humans. This review presents the future perspective of resolving this crisis through an accelerated composting process involving antibiotic degrading microbes.

\section{Nutrient Content of Poultry Feed and Excreta}

Poultry manure quality starts with the quality of the poultry feed. Therefore, in order to evaluate the nutrient content of the poultry waste, it is important to know the poultry feed composition because a considerable proportion of the feed passes through the body unabsorbed and thus reaches the poultry litter. The largest composition of poultry feed contains carbon sources from rice, wheat, sorghum and corn [20]. In addition to that, it also contains protein (nitrogen) sources from soy meal, canola, lentils and sunflower sources. Fishmeal, meat and bone meal are also important protein sources in poultry feeds [21]. Poultry feed also contains mineral supplements which include calcium from limestone, shell grit, dicalcium phosphates, defluorinated rock phosphate, bone meal, mineral premixes like sodium salt, sodium bicarbonate. Furthermore, vitamins, amino acids like methionine, lysine, threonine, enzymes and antibiotics, pesticides, acaricides and other food supplements also constitute some percentage of the poultry feeds [22].

Most of the poultry feed components pass through the animals' gut partially or completely undigested hence the poultry litter consists of undigested nitrogen $(\mathrm{N})$, phosphorus $(\mathrm{P})$ and considerable amounts of other substances such as hormones, antibiotics and heavy metals [23,24]. Due to the inefficient conversion of dietary nitrogen in poultry birds, $55-80 \%$ of the total nitrogen is excreted [25-27]. Further, the broiler chicken also excretes approximately up to $80 \%$ of the phosphorous and $80 \%$ of the potassium and $50 \%$ to $80 \%$ of the nitrogen [28]. P is partly present in poultry diets as 
phytic phosphorus, i.e., a form that is poorly digestible by birds due to a lack of adequate endogenous phytase activity [23].

\section{Significance of Poultry Manure}

Uncomposted poultry litter contains a huge amount of organic carbon, nitrogen and phosphorus which rarely support the growth of crop plants. Therefore, the litter becomes usable only after composting, yielding what we mention in this review as 'poultry compost'. Subsequent to composting for a considerable period of time, the concentration of nitrogen (3-5\%), phosphorous $(1.5-3.5 \%)$ and potassium (1.5-3.0\%) changes leading to accelerated compost properties [29-31]. Further, it is also been reported to contain all the essential micronutrients for plants such as calcium $(\mathrm{Ca})$, magnesium $(\mathrm{Mg})$, sulfur $(\mathrm{S})$, manganese $(\mathrm{Mn})$, copper $(\mathrm{Cu})$, zinc $(\mathrm{Zn})$, chlorine $(\mathrm{Cl})$, boron $(\mathrm{B})$, iron (Fe) and molybdenum (Mo) at considerable levels [31-33]. Thus, it is clear that the composted poultry manure contains enough quantities of nutrients that can support not only crop yield but also enhance the physicochemical properties of the soil. As a matter of fact, the application of poultry manure improves the irrigation efficiency and dryness resistance of sandy soils by enhancing the moisture retention capacity and lateral water movement of the soil. This causes longstanding plant nutrient retention in soils thereby rendering extended uptake of nutrients in plants [34-37]. In addition to that, poultry manure also promotes the microbial community in the soil. These microbes support plant growth and offer protection against various plant pathogens [38-40].

\section{Microbial Content of Poultry Litter}

Lu et al. [41] evaluated the microbial composition of broiler litter using 16S rRNA and Functional Gene Markers. Their report revealed that Enterococcus sp. and Coliforms were detected by culture-based bacterial detection, while culture independent methods revealed other group of bacteria such as Globicatella sulfidofaciens, Corynebacterium ammoniagenes, Corynebacterium urealyticum, Clostridium aminovalericum, Arthrobacter sp. and Denitrobacter permanens. Other bacterial strains with pathogenic character such as Clostridia, Staphylococci and Bordetella sp. were also reported when poultry litter DNA samples were used as templates for microbial diversity assessment [41]. Enticknap et al. 2006 [42] had identified a variety of bacterial species namely Nocardiopsis sp., Anthrobacter sp., Brachybacterium sp., Brevibacterium avium, Cornibacterium ammoniagenes, Clostridium lituseburense, Lactobacillus avarius, Jeotgaloccus pinnipedialis, Paraliobacillus ryukyuensis, Virgibacillus carmonensis and few other Bacillus species that are responsible for the production of fertilizer from poultry litter. Wet and dry poultry litter samples exhibited the presence of bacterial strains such as Aerococcus viridans, Atopostipes suicloacalis, Bacillus hackensackii, Brevibacterium avium, Corynebacterium ammoniagenes, Facklamia sourekii, Jeotgalicoccus sp., Salinicoccus halodurans, Staphylococcus arlettae, Staphylococcus cohnii and Virgibacillus marismortui in which Staphylococcus, Salinicoccus, Virgibacillus, Jeotgalicoccus, Facklamia, Brevibacterium and Bacilli were found to be dominant. In addition to these, fungal species such as Candida sp., Penicillium pimiteouiense, Penicillium decumbens, Aspergillus sydowii and Euroteum amstelodami were also identified from the above samples [43]. Food borne bacterial pathogens namely E. coli, Salmonella, Campylobacter, Staphylococcus, Clostridium, Listeria, Actinobacillus and Mycobacterium were also frequently detected in poultry litter [44].

\section{Soil Amendment}

The manure from chicken, pigs and cows are being used not only for agricultural purposes but also as a feedstock for biogas production. Numerous studies have revealed the various ways how poultry manure prove useful. The addition of poultry litter to tall fescue, orchard grass, Bermuda grass has led to increase in dry matter production [45]. Poultry manure has also been used for the restoration of soil polluted by mining and industrial activities. Poultry manure application increases organic matter and soil moisture contents and water-holding capacity, that in turn improve soil conditions by effecting the indigenous microbial activity enhancing maize yields (Table 1) [46]. 
Table 1. Characteristics of processed poultry waste-based animal feeds (FDA, 2009).

\begin{tabular}{ccccccc}
\hline Category & Description & $\begin{array}{c}\text { Moisture } \\
\text { Content (\%) }\end{array}$ & $\begin{array}{c}\text { Crude } \\
\text { Protein\% }\end{array}$ & $\begin{array}{c}\text { Crude } \\
\text { Fiber\% }\end{array}$ & Ash\% & Feathers\% \\
\hline Dried poultry waste & $\begin{array}{c}\text { Feces } \\
\text { Void of part or all of } \\
\text { crude protein } \\
\text { and non-protein } \\
\text { nitrogen, feces }\end{array}$ & $>15$ & $<18$ & $>15$ & $>30$ & $>1$ \\
Dried poultry waste & $>15$ & $<11$ & $>15$ & $>30$ & $>1$ \\
\hline
\end{tabular}

\subsection{As Animal Feed}

Poultry litter, either standalone or when mixed with feed grains, is a valuable feed for cattle and fish [47]. However, on the other hand, this practice has raised serious concerns on the safety of using animals waste, with respect to pathogen and disease problems. $\mathrm{Cu}$ toxicity has been found to be a major concern especially in sheep fed with poultry manure, more so in sheep since they are less tolerant to high dietary levels of $\mathrm{Cu}$ than other livestock species $[48,49]$. Poultry litter has been used in the United States as animal feed for over 40 years. The specifications for use of poultry litter as an animal feed and the variations in some of its characteristics have been reported [46].

\subsection{As Fuel}

Poultry litter is also being used as fuel in cooking and lighting. It can be burnt directly to produce heat. In many countries around the globe, poultry waste is converted into biogas, whose main constituent is methane, $60 \%$, carbon dioxide $38 \%$, water vapor, hydrogen and hydrogen sulfide. Biogas can be used for the internal combustion engine of farm tractors to generate electricity. Poultry litter combustion has also received major attention in order to produce heat and electricity at large centralized facilities [50]. In the pursuit for generating electric power from renewable 'green' sources, a number of cities in the States have turned to thermal conversion of biomass. For example, Minnesota produces over two million tons of turkey and broiler waste-the fuel for 'poultry power.' Now some Minnesota turkey farmers are working with a British company (Fibrowatt, Langhorne, PA, USA) that built a manure-powered power plant in central Minnesota (http://fibrowattusa.com). The plant burns nearly half a million tons of poultry litter every year, generating $50 \mathrm{MW}$ of electricity that will be sufficient to supply 40,000 households. The major constraint with the use of poultry litter is the high moisture content and the odor it produces during storage and composting.

\section{Composting Process of Poultry Manure}

Organic waste composting is a microbially mediated biooxidative process that yields a stabilized final product without pathogens, phytotoxic compounds and plant seeds that affect plant growth and productivity through mineralization and partial humification of the organic matter [10]. During the initial phase of the composting process, the simple organic carbon compounds are easily mineralized and metabolized by diverse groups of microorganisms such as bacteria, fungi and micro arthropods to produce $\mathrm{CO}_{2}, \mathrm{NH}_{3}, \mathrm{H}_{2} \mathrm{O}$ and organic acids. Once the mesophilic microorganisms encounter organic material, they self-assemble into self-insulating masses, accelerating their growth and metabolism resulting in a rapid increase of temperature that limits mesophilic bacterial growth and stimulates the thermophilic bacterial growth [51]. This extensive microbial metabolic process generates enormous heat energy that raises the temperature of the pile and consequently reduces the volume of the poultry litter wastes [41,52]. Thermophilic composting conditions have resulted in the complete annihilation of lethal gram- negative enteric and pathogenic poultry viruses [53]. 


\section{Factors Affecting Composting Process}

Successful composting totally relies on microbial decomposition process which in turn depends on various factors such as moisture content, $\mathrm{pH}$, particle size of the poultry litter, compost duration, free air space at which the optimal microbial metabolism is being performed and moreover to the core carbon:nitrogen (C:N) ratio of the poultry litter [54]. It has been reported that the best compost was achieved only at optimum levels of the following factors i.e., carbon:nitrogen (C:N) ratio (between 15 and 25), moisture content (between 40 and 60\%), pH (between 5 and 12) and greater than $30 \%$ free air space at which the optimal microbial metabolism is being performed [55,56]. Even though the $\mathrm{pH}$ and temperature are crucial factors to consider in the composting process, their control had not been usually applied in practical composting operations in full-scale composting systems [57-59]. However, the nutrient factor-the C:N ratio-had often been studied as the main factor that controls the poultry composting process. Although, the composting process is carried out under a broad range of initial $\mathrm{C} / \mathrm{N}$ ratios, (11 to 105$)$ which generally depend on the starter materials $[60,61]$. Extremely low and high C:N ratios of the compost material yielded low-quality compost with inferior qualities [16,62]. Different co-composting materials were also used to enhance the C:N ratio as well as to reduce the $\mathrm{N}$ loss. When the poultry litter was co-composted with biochar, the $\mathrm{N}$ losses were reduced up to $25 \%$ by lowering the ammonia concentration up to $64 \%$ [63]. The co-addition of poultry litter with olive mill waste and mineral rich wastewater as a co-composting material yielded a compost with superior qualities i.e., free of phytotoxicity and no negative impacts on soils [64]. Poultry litter co-composting with various substrates such as wood shaving, excess feed and feathers resulted in compost containing stable organic matter [16]. In addition to that, when pineapple leaves and chicken slurry were used as the initial co-composting material with poultry litter, the compost resulted in an odorless final product with low heavy metals content and substantial amounts of nutrients [65]. Recently, coir pith waste and sugarcane tops are being used as efficient co-composting material of poultry litter $[66,67]$. Thus, the effect of most of the crucial factors that contribute towards the poultry litter composting processes have been evaluated. However, the role of antibiotics in the composting process of poultry litter which is yet another crucial factor remains overlooked and sidelined. This factor is able to directly affect the microbial community that initiates the primary decomposition process and microbial succession during the composting process.

\section{Antibiotics Used in Poultry}

Antibiotics (as therapeutic agents and as growth-promoting antibiotics (GPAs)) are used in the poultry industry for disease prevention and growth promotion. Their use has been tremendously increased from the 1950s in order to enhance growth, feed efficiency and reduce mortality in broiler production [68-71]. Owing to frequent controversies regarding the impact of antibiotics used in livestock affecting human health, various public organizations such as The World Health Organization, the American Medical Association and the American Public Health Association have urged a ban on growth-promoting antibiotics (GPAs). They argue that their use leads to increased antibiotic-resistant infections in humans $[72,73]$. However, the regular inclusion of antibiotics as feed additives to promote growth in the diets of commercial poultry breed still continues as a standard practice in developing and underdeveloped countries. Van Boeckel et al. [74] estimated that the global average annual consumption of antimicrobials per kilogram of poultry animals produced during 2010 was $148 \mathrm{mg} \mathrm{kg}^{-1}$. This was found to be much higher than the consumption in cattle, and the study further predicted that the global antimicrobial consumption in the livestock industry will alarmingly increase to $67 \%$, from $63,151 \pm 1560$ tons to $105,596 \pm 3605$ tons by 2030 .

A vast diversity of antibiotics have been administered in the poultry industry as feed additives as antibiotic growth promoters (AGPs) and also to treat the birds against pathogenic diseases. Table 2 summarizes the various classes of antibiotics such as ionophores, glycopeptide antibiotics, orthosomycins, diterpene antibiotics, tetracyclines, aminoglycosides, cyclic peptides, lincosamides, polymyxins, fluoroquinolone, sulfonamides, macrolides, streptogramins, quinolones, 
diaminopyrimidines and $\beta$-Lactams that were and are being used for poultry including, chickens, turkeys, ducks, ostriches, pigeons, pheasants and quails.

Table 2. Antibiotics used in poultry industry for the treatment of microbial diseases and also as feed additives as antibiotic growth promoters (AGPs).

\begin{tabular}{|c|c|c|c|c|}
\hline Antibiotics Used in Poultry & $\begin{array}{l}\text { Activity Against Microbial } \\
\text { Pathogens }\end{array}$ & Mode of Action & Used for Poultry Species & Reference \\
\hline Ionophores & & & & \\
\hline $\begin{array}{c}\text { flavomycin/bambermycin/ } \\
\text { flavophospholipol, moenomycin }\end{array}$ & Gram-positive bacteria & $\begin{array}{l}\text { Inhibition of cell } \\
\text { wall synthesis }\end{array}$ & broiler chicken and turkeys & {$[75,76]$} \\
\hline maduramicin, narasin and monensin & protozoan parasite (Eimeria sp.) & $\begin{array}{l}\text { Cell wall } \\
\text { disruption }\end{array}$ & broilers & {$[77,78]$} \\
\hline lasalocid & protozoan parasite (Eimeria sp.) & $\begin{array}{l}\text { Cell wall } \\
\text { disruption }\end{array}$ & $\begin{array}{l}\text { broilers and replacement pullets, } \\
\text { turkeys, pheasants and quails. }\end{array}$ & [79] \\
\hline salinomycin & protozoan parasite (Eimeria sp.) & $\begin{array}{l}\text { Cell wall } \\
\text { disruption }\end{array}$ & chicken and turkey & [80] \\
\hline semduramicin & protozoan parasite (Eimeria sp.) & $\begin{array}{l}\text { Cell wall } \\
\text { disruption }\end{array}$ & chicken and turkey & [81] \\
\hline nystatin & Candida albicans & $\begin{array}{l}\text { Cell wall } \\
\text { disruption }\end{array}$ & chicken and turkey & [82] \\
\hline \multicolumn{5}{|l|}{ Glycopeptide antibiotic } \\
\hline avoparcin & Gram-positive bacteria & $\begin{array}{l}\text { Inhibition of cell } \\
\text { wall synthesis }\end{array}$ & Broiler chicken and turkeys & {$[78,83,84]$} \\
\hline $\begin{array}{c}\text { vancomycin, teicoplanin, avoparcin, } \\
\text { ardacin }\end{array}$ & $\begin{array}{c}\text { Gram-positive bacteria } \\
\text { and Actinomycetes such as } \\
\text { Streptomyces orientalis (vancomycin), } \\
\text { Nocardia actinoides (Actinoidin) }\end{array}$ & $\begin{array}{l}\text { Inhibition of cell } \\
\text { wall synthesis }\end{array}$ & Broiler chickens and Turkey & [85-87] \\
\hline \multicolumn{5}{|l|}{ Orthosomycin } \\
\hline avilamycin & Gram-positive bacteria & $\begin{array}{l}\text { Inhibition of } \\
\text { protein synthesis }\end{array}$ & Broiler chicken and turkeys & [88-92] \\
\hline $\begin{array}{l}\text { Diterpene antibiotics } \\
\text { tiamulin hydrogen }\end{array}$ & Mycoplasma and Brachyspira & $\begin{array}{l}\text { inhibition protein } \\
\text { synthesis }\end{array}$ & Broilers chickens & [93] \\
\hline $\begin{array}{l}\text { Tetracyclines } \\
\text { chlortetracycline, doxycycline, } \\
\text { oxytetracycline, tetracycline }\end{array}$ & $\begin{array}{l}\text { Gram-positive and Gram-negative } \\
\text { bacteria, Mycobacterium, Mycoplasma, } \\
\text { Nocardia, Streptomyces and Ureaplasma }\end{array}$ & $\begin{array}{l}\text { inhibition protein } \\
\text { synthesis }\end{array}$ & $\begin{array}{l}\text { Turkeys, Pigeons, Ostriches, } \\
\text { ducks }\end{array}$ & [94-96] \\
\hline $\begin{array}{c}\text { Aminoglycosides } \\
\text { gentamicin, tobramycin, amikacin, } \\
\text { streptomycin, kanamycin, neomycin, } \\
\text { spectinomycin } \\
\text { Cyclic peptide }\end{array}$ & Gram-positive and negative bacteria & Tetracyclines & $\begin{array}{l}\text { Broiler chickens, Ducks } \\
\text { and Turkeys }\end{array}$ & [97-99] \\
\hline bacitracin/zinc bacitracin & $\begin{array}{l}\text { Gram-positive and Gram-negative } \\
\text { Bacteria }\end{array}$ & $\begin{array}{l}\text { Inhibition of Cell } \\
\text { wall and protein } \\
\text { synthesis }\end{array}$ & Layers, Turkeys, Ducks, pigeons & [3] \\
\hline $\begin{array}{l}\text { Lincosamides } \\
\text { Lincomycin, Clindamycin } \\
\text { and Pirlimycin } \\
\text { Polymixins }\end{array}$ & $\begin{array}{l}\text { Mycoplasma and Gram-positive } \\
\text { anaerobes }\end{array}$ & $\begin{array}{l}\text { Inhibition of } \\
\text { protein synthesis }\end{array}$ & Chickens & {$[3,100,101]$} \\
\hline polymixin B, colistin (polymyxin E) & Gram-negative bacteria & $\begin{array}{l}\text { Inhibition of cell } \\
\text { membrane function }\end{array}$ & Chickens & {$[102,103]$} \\
\hline $\begin{array}{c}\text { Fluoroquinolones } \\
\text { ciprofloxacin, ofloxacin. trimethoprim } \\
\text { enrofloxacin marbofloxacin } \\
\text { and difloxacin } \\
\text { sulfonamides }\end{array}$ & Gram-negative bacteria & $\begin{array}{l}\text { Inhibition of DNA } \\
\text { replication }\end{array}$ & Chickens, Turkey and Ducks & [104-106] \\
\hline sulfadimidine, sulfamethoxazole. & $\begin{array}{c}\text { Gram-positive and Gram-negative } \\
\text { bacteria and Protozoa }\end{array}$ & $\begin{array}{l}\text { Inhibition DNA } \\
\text { replication }\end{array}$ & $\begin{array}{l}\text { Broiler and Layer Chickens } \\
\text { and Turkeys }\end{array}$ & [107-109] \\
\hline $\begin{array}{l}\text { Macrolides } \\
\text { azithromycin, clarithromycin, } \\
\text { clindamycin, erythromycin, } \\
\text { roxithromycin, spiramycin, tylosin, } \\
\text { vancomycin } \\
\text { Streptogramins }\end{array}$ & $\begin{array}{c}\text { Gram-positive bacteria, Mycoplasma, } \\
\text { Mycobacteria, some Rickettsia } \\
\text { and Chlamydia }\end{array}$ & $\begin{array}{l}\text { Inhibition of } \\
\text { protein synthesis }\end{array}$ & Layer and broilers Chickens & [110-113] \\
\hline virginiamycin & Gram-positive bacteria & $\begin{array}{l}\text { Inhibition of } \\
\text { protein synthesis. } \\
\text { Inhibit Protein } \\
\text { synthesis }\end{array}$ & $\begin{array}{c}\text { Chickens and Turkeys } \\
\text { Broiler chickens }\end{array}$ & $\begin{array}{c}{[86,114-} \\
116] \\
{[86,114-} \\
116]\end{array}$ \\
\hline $\begin{array}{l}\text { Quinolones } \\
\text { quinoxalines }\end{array}$ & Gram-positive Organisms & $\begin{array}{l}\text { Inhibition of DNA } \\
\text { replication }\end{array}$ & Chickens and Turkey & [116] \\
\hline $\begin{array}{c}\text { Diaminopyrimidines } \\
\text { Trimethoprim, aditoprim, } \\
\text { baquiloprim, ormetoprim } \\
\beta \text {-Lactams }\end{array}$ & $\begin{array}{l}\text { Gram-positive and many } \\
\text { Gram-negative bacteria }\end{array}$ & $\begin{array}{l}\text { Inhibition of DNA } \\
\text { replication }\end{array}$ & Chickens & [117] \\
\hline $\begin{array}{l}\text { Penicillins: amoxicillin, ampicillin, } \\
\text { benzylpenicillin, cloxacillin, } \\
\text { dicloxacillin, flucloxacillin, } \\
\text { methicillin, mezlocillin, nafcillin, } \\
\text { oxacillin, piperacillin, } \\
\text { phenoxymethylpenicillin }\end{array}$ & $\begin{array}{l}\text { Gram-positive and many } \\
\text { Gram-negative bacteria }\end{array}$ & $\begin{array}{l}\text { Inhibition of cell } \\
\text { wall synthesis }\end{array}$ & $\begin{array}{l}\text { Fattening Turkeys Broiler } \\
\text { Chickens }\end{array}$ & [118-121] \\
\hline
\end{tabular}


Ionophores are ion-carrier molecules that facilitate ion transport across lipid membrane due to their lipid-soluble nature and reversible ion binding ability. The ionophores used in the poultry industry as feed additives are predominantly obtained from Streptomyces and other fungal species as their fermentation products [122].They are used extensively as anticoccidials and they act against the protozoan parasite Eimeria species and Gram-positive bacteria in broiler chicken, turkeys, pheasants and quails. They exhibit antimicrobial activity by binding to the cell wall (ergosterol) and facilitate extensive leakage of cellular $\mathrm{K}^{+}$ions which results in acidification and death of the poultry pathogens. In the poultry industry ionophore antibiotics such as bambermycin/flavomycin, maduramicin, narasin, monensin, lasalocid, salinomycin, semduramicin and nystatin were used as feed additives [75-78].

Glycopeptide antibiotics fall under the category of antibiotics that have glycosylated cyclic or polycyclic nonribosomal peptides, and interfere with the cell wall and protein synthesis of enterococcal pathogens. However, their application was extremely limited for the fear of creating methicillin-resistant strains of Staphylococcus aureus (MRSA) in poultry chicken and their presumable infectivity in humans. Therefore, in most of the developed countries the usage of glycopeptides antibiotics had been banned [85]. The FDA Center for Veterinary Medicine (FDA-CVM) also issued an order following the European ban on vancomycin in 1997 prohibiting the extra-label use of all glycopeptides in food animals [123]. However, the usage of such antibiotics is yet to be strictly monitored in under-developed countries.

Avilamycin-a drug from the orthosomycin family (due to its orthoester links with carbohydrates moieties)-is also used as a growth promoter in broiler chickens and turkeys [124]. The drug effectively controls the Gram-positive bacterial community structure in poultry birds through the inhibition of ribosomal function and subsequent protein synthesis in bacteria [116,125]. A diterpene antibiotic namely tiamulin hydrogen fumarate, a semi synthetic derivative of pleuromutilin was found to be effective against different Mycoplasma- and Brachyspira-related diseases in poultry chickens and turkeys through inhibiting protein synthesis $[93,126]$.

Tetracyclines, are yet another well-known group of antibiotics used to control various groups of disease causing microorganisms in poultries such as gram positive and gram negative bacteria; Mycobacterium, Mycoplasma, Nocardia, Streptomyces and Ureaplasma. The tetracycline derivatives like chlortetracycline, doxycycline, oxytetracycline, tetracycline are used to control pathogens and thereby aid in improving the feed efficiencies and promote growth in chickens, turkeys, pigeons, ostriches, ducks. They also act through the inhibition of protein synthesis [94-96,100]. For treatment of diseases caused by some mycoplasma and Gram-positive anaerobes in poultry chickens, antibiotics from the lincosamides group namely lincomycin, clindamycin and pirlimycin. that interfere with protein synthesis are also used $[3,100,110]$. Respiratory diseases and gastrointestinal infections caused by Pseudomonas aeruginosa in poultry chickens, turkeys and ducks have often been treated with fluoroquinolone group of antibiotics i.e., ciprofloxacin, ofloxacin. Trimethoprim Enrofloxacin, marbofloxacin and difloxacin that block DNA replication [104-106]. Macrolides such as azithromycin, clarithromycin, clindamycin, erythromycin, roxithromycin, spiramycin, tylosin are prevalently administered with feed of layer and broiler chickens against beta-hemolytic Streptococci, Pneumococci, Staphylococci and Enterococci, Mycoplasma, Mycobacteria, some Rickettsia and Chlamydia infections and their mode of action was also through the inhibition of protein synthesis [110-113]. Antibiotics belonging to the streptogramins group and quinolones namely virginiamycin and nosiheptide, specifically act against Gram-positive bacterial infections by blocking protein synthesis of those pathogens in chickens and turkeys [86,114-116]. Diaminopyrimidines such as Trimethoprim, aditoprim, baquiloprim, ormetoprim often act as bactericidal agents in the presence of sulfonamides against Gram-positive and many Gram-negative bacteria through the inhibition of nucleic acid synthesis [117]. The traditional antibiotic group called $\beta$-Lactams was observed to be used in poultries. Various derivatives of penicillins such as amoxicillin, ampicillin, benzylpenicillin, cloxacillin, dicloxacillin, flucloxacillin, methicillin, mezlocillin, nafcillin, oxacillin, piperacillin, phenoxymethylpenicillin are predominantly used for controlling infections such as Necrotic enteritis, ulcerative enteritis and intestinal spirochetosis in poultry caused by Enterococcus 
faecalis. The antibiotics inhibit cell wall synthesis [118-121]. Aminoglycosides antibiotics such as gentamicin, tobramycin, amikacin, streptomycin, kanamycin, neomycin, spectinomycin, have also been used invariably in broiler chickens, ducks and turkeys. These drugs exhibit great control over pathogenic Gram-positive and negative bacteria through inhibiting bacterial protein synthesis [97-99]. In addition to that, cyclic peptide antibiotics, bacitracin and its derivative zinc bacitracin, which inhibit the bacteria through blocking protein synthesis have been used to control both Gram-positive and negative bacteria that causes diseases in layer chickens, turkeys, ducks and pigeons [3]. polymyxins such as polymyxin B, colistin (polymyxin E) have also been prevalently used to control disease caused by most Gram-negative bacteria in chickens [102,103,127].

Thus, the commercial poultry farming is adequately supplied with umpteen numbers of antibiotics in large quantities and therefore it is believed and established that a large portion of the unmetabolized antibiotics could possibly be excreted out and stay longer in poultry litter which would not only act against the poultry associated microflora but also work against common beneficial microflora that involve in the composting process. The concentration of antibiotics administered, and the residual antibiotics excreted in poultry litter have been extensively reviewed. It is a well-known fact that almost all the antibiotics used in poultry industry are minimally metabolized and excreted via urine and feces of birds, for instance tyrosine used in poultry chicken, is excreted primarily in urine to a larger extent and the remaining through feces $[128,129]$. Some aspects have been addressed in a review by Goetting et al. 2011 [130] on the pharmacokinetics of drugs used for layering chicken. Most of the antibiotics used in poultry are concentrated in poultry litter unmetabolized to a major extent, another review on global antibiotic poultry antibiotic usage and their in-tissue assimilation by Van Boeckel et al. [74] is also informative. The data of antibiotic residues of poultry chicken in various nations was reviewed by Mauz et al. 2018 [131]. These existing reviews report the concentrations and antibiotic residues, in chicken meat and not in chicken litter. All these are restricted to residues in the meat. There is no information or detailed study on the concentration of the antibiotics in the poultry litter and more so almost no information on the residual antibiotic concentration in the poultry compost (the pretreated poultry litter used for agricultural purposes). The subsequent residual antibiotic concentrations released to the soil when the compost has been used in the soil and thereafter the residual concentrations carried over to the plants/ agricultural crops have not been studied. There are many gray areas in this area. This review identifies this lacuna and emphasizes that this is the need of the hour. An enlightenment in this area could bring about an awareness on the environmental and toxicological impact of this flow.

\section{Future Prospects}

After contamination of niches with antibiotics, these have become one of the vital ecological factors in any of the ecosystems that influence the evolution of the community structure [132]. Subsequently, the community structural changes in turn affect the ecosystem functions such as biomass production and nutrient transformation $[133,134]$. Therefore, there is no doubt that the poultry litter, before composting, contains a large quantity of a wide variety of antibiotics and its entry into the food chain at various levels needs to be closely monitored. Furthermore, it has been reported that the potential antibiotic effect that influence the community structure stays for a prolonged period (e.g., sulfadiazine up to 175 days) [135]. Although many research works concerning the poultry compost preparation have taken various factors such as $\mathrm{C} / \mathrm{N}$ ratio, moisture content etc., into consideration during the optimization of the composting process, the role of antibiotics, in the poultry composting process has not been studied so far. Composting involves the involvement of the activity of the inherent microbes in the litter, so antibiotics in the poultry litter affecting the microbial diversity of the poultry litter will crucially affect the successful composting process. Therefore, studying the fate of antibiotics in the poultry litter is a crucial prerequisite since it invariably affects human beings either directly through consumable poultry based products or indirectly through inhibiting the agriculturally beneficial microbial population in the poultry waste. Furthermore, the antibiotic load in poultry litter would 
certainly affect the biooxidative process and thus compost maturity would be largely delayed, which is yet another main factor that needs to be considered. All these gray areas specified, and issues raised, are yet to be addressed. This review hopes that a sensitization and awareness triggering research in these associated areas will ignite.

The other prophylaxis is through the deliberate addition of microbial isolates that hold a reputation as antibiotic degraders and hydrolytic enzyme producers, to the poultry litter at the very initial stage of composting for accelerating the composting process. This would ideally degrade the antibiotics in the poultry litter and create a congenial environment for the composting process to take its course. Figure 1 sums up the current and the future prospects of poultry litter management. This review emphasizes on the introduction of antibiotic degraders as a mandatory prerequisite for accelerated microbially mediated composting of poultry litter, for effective composting and for environmentally friendly antibiotic free accelerated production of poultry compost for agricultural use.

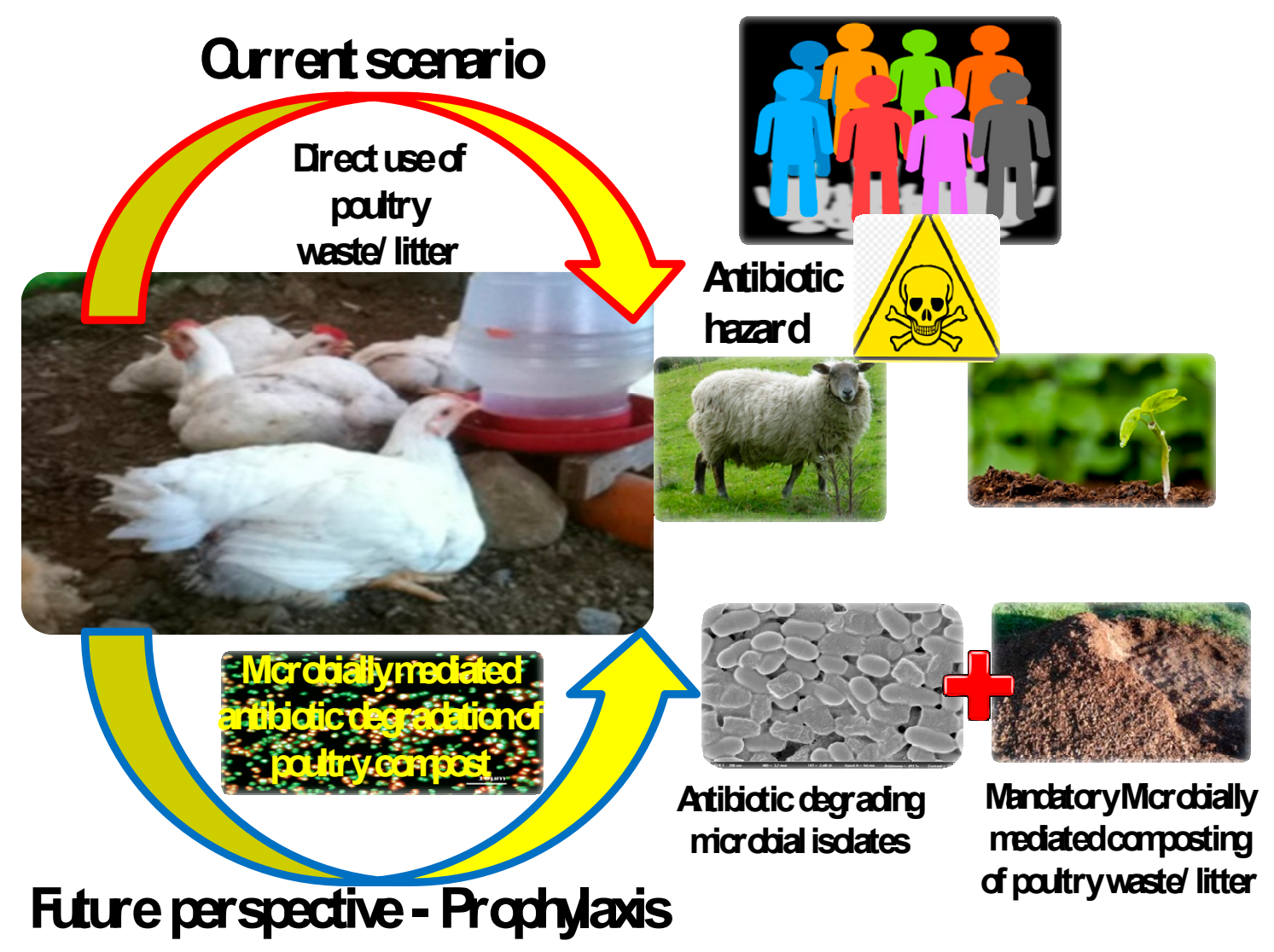

Figure 1. Schematic emphasizing the futuristic environmentally friendly and promising microbially accelerated poultry waste/litter composting.

\section{Conclusions}

This review has questioned the fate of residual antibiotic in poultry waste that has the potential to negatively impact microbial communities that are involved in microbial mediated poultry litter composting processes. The incorporation of antibiotic degrading environmental isolates in poultry litter at the initial stage of composting in order to accelerate the process is addressed in this review as a future perspective. This review aims at creating an awareness and sensitization in this direction.

Author Contributions: Conceptualization, writing, original draft preparation, M.M., Z.K. and S.C.; review and editing, J.G., U.B.S., J.-W.O. All authors have read and agree to the published version of the manuscript.

Funding: This research received no external funding. 
Conflicts of Interest: The authors declare no conflict of interest.

Ethical Approval: This article does not contain any studies with human participants or animals performed by any of the authors.

\section{References}

1. Upali Wickramasinghe, G.A. Meat and Meat products. In Food Outlook, Food and Agricultural Organization; United Nations FAO Investment Centre Division: Rome, Italy, 2018; pp. 48-53.

2. Jones, B.E.H.; Haynes, R.J.; Phillips, I.R. Effect of amendment of bauxite processing sand with organic materials on its chemical, physical and microbial properties. J. Environ. Manag. 2010, 91, 2281-2288.

3. Castanon, J.I.R. History of the use of antibiotic as growth promoters in European poultry feeds. Poult. Sci. 2007, 86, 2466-2471. [PubMed]

4. Collins, E.R.; Barker, J.C.; Carr, L.E.; Brodie, H.L.; Martin, J.H. National Resource, Agriculture, and Engineering Service. In Poultry Waste Management Handbook; Cornell University: Ithaca, NY, USA, 1999.

5. Williams, C.M.; Barker, J.C.; Sims, J.T. Management and utilization of poultry wastes. Rev. Environ. Contam. Toxicol. 1999, 162, 105-157.

6. Mitchell, C.C.; Donald, J.O.; Martin, J. The Value and Use of Poultry Waste as Fertilizer; Alabama Cooperative Extension System: Auburn, AL, USA, 1995.

7. Kelleher, B.P.; Leahy, J.J.; Henihan, A.M.; O’Dwyer, T.F.; Sutton, D.; Leahy, M.J. Advances in poultry litter disposal technology-A review. Bioresour. Technol. 2002, 83, 27-36.

8. Britto, D.T.; Kronzucker, H.J. $\mathrm{NH}_{4}{ }^{+}$toxicity in higher plants: A critical review. J. Plant Physiol. 2002, 159, 567-584.

9. Qin, C.; Yi, K.K.; Wu, P. Ammonium affects cell viability to inhibit root growth in Arabidopsis. J. Zhejiang Univ. Sci. B 2011, 12, 477-484. [PubMed]

10. Zucconi, F.; De Bertoldi, M. Compost specifications for the production and characterization of compost from municipal solid waste. In Compost: Production, Quality and Use; De Bertoldi, M., Ferranti, M.P., L'Hermite, M.P., Zucconi, F., Eds.; Elsevier: London, UK, 1987; pp. 276-295.

11. Garces, A.; Afonso, S.M.S.; Chilundo, A.; Jairoce, C.T.S. Evaluation of different litter materials for broiler production in a hot and humid environment: 1. Litter characteristics and quality. J. Appl. Poult. Res. 2013, 22, 168-176.

12. Sweeten, J.M. Composting manure and sludge. In Proceedings of the National Poultry Waste Manage Symposium, Columbus, OH, USA, 18-19 April 1988; pp. 38-44.

13. Kithome, M.; Paul, J.W.; Bomke, A.A. Reducing nitrogen losses during simulated composting of poultry manure using adsorbents or chemical amendments. J. Environ. Qual. 1999, 28, 194-201.

14. Gao, M.C.; Li, B.; Yu, A.; Liang, F.Y.; Yang, L.J.; Sun, Y.X. The effect of aeration rate on forced-aeration composting of chicken manure and sawdust. Bioresour. Technol. 2010, 101, 1899-1903. [PubMed]

15. Gao, M.C.; Liang, F.Y.; Yu, A.; Li, B.; Yang, L.J. Evaluation of stability and maturity during forced-aeration composting of chicken manure and sawdust at different $C / N$ ratios. Chemosphere 2010, 78, 614-619.

16. Tiquia, S.M.; Tam, N.F.Y. Fate of nitrogen during composting of chicken litter. Environ. Pollut. 2000, 110, 535-541. [PubMed]

17. Shen, Y.; Ren, L.; Li, G.; Chen, T.; Guo, R. Influence of aeration on $\mathrm{CH}_{4}, \mathrm{~N}_{2} \mathrm{O}$ and $\mathrm{NH}_{3}$ emissions during aerobic composting of a chicken manure and high $\mathrm{C} / \mathrm{N}$ waste mixture. Waste Manag. 2011, 31, 33-38. [PubMed]

18. Mahimairaja, S.; Bolan, N.S.; Hedley, M.J.; Macgregor, A.N. Losses and transformation of nitrogen during composting of poultry manure with different amendments: An incubation experiment. Bioresour. Technol. 1994, 47, 265-273.

19. Kajiya, Y.; Ishii, Y.; Fukuyama, K.; Idota, S. Precise optimization of poultry mnure composting using an experimental small-scale apparatus. J. Biol. Sci. 2015, 15, 40-44.

20. Ravindran, V.; Blair, R. Feed resources for poultry production in Asia and the Pacific region. I. Energy sources. World Poult. Sci. J. 1991, 47, 213-231.

21. Williams Beski, S.S.M.; Swick, R.A.; Iji, P.A. Specialized protein products in broiler chicken nutrition: A review. Anim. Nutr. 2015, 1, 47-53. 
22. Ravindran, V. Poultry feed availability and nutrition in developing countries. In Poultry Development Review; FAO: Rome, Italy, 2013; pp. 60-63.

23. Dilger, R.N.; Adeola, O. Estimation of true phosphorus digestibility and endogenous phosphorus loss in growing chicks fed conventional and low-phytate soybean meals. Poult. Sci. 2006, 85, 661-668.

24. Nahm, K.H. Feed formulations to reduce N excretion and ammonia emission from poultry manure. Bioresour. Technol. 2007, 98, 2282-2300.

25. Gerber, P.; Opio, C.; Steinfeld, H. Poultry production and the environment-A review in Poultry in the 21st Century. In Proceedings of the International Conference Poultry in the Twenty-First Century: Avian Influenza and Beyond, Bangkok, Thailand, 5-7 November 2007; pp. 379-405.

26. Arogo, J.; Westerman, P.W.; Heber, A.J.; Robarge, W.P.; Classen, J.J. Ammonia in Animal Production-A Review; Paper number 014089, ASAE Annual Meeting; American Society of Agricultural and Biological Engineers: St. Joseph, MI, USA, 2001.

27. Latshaw, J.D.; Zhao, L. Dietary protein effects on hen performance and nitrogen excretion. Poult. Sci. 2011, 90, 99-106.

28. Leytem, A.B.; Plumstead, P.W.; Maguire, R.O.; Kwanyuen, P.; Brake, J. What aspect of dietary modification in broilers controls litter water-soluble phosphorus: Dietary phosphorus, phytase, or calcium? J. Environ. Qual. 2007, 36, 453-463.

29. Nahm, K.H. Evaluation of the nitrogen content in poultry manure. World Poult. Sci. J. 2003, 59, 77-88.

30. Chen, L.J.; Xing, L.; Han, L.J. Quantitative determination of nutrient content in poultry manure by near infrared spectroscopy based on artificial neural networks. Poult. Sci. 2009, 88, 2496-2503. [PubMed]

31. Amanullah, M.M.; Sekar, S.; Muthukrishnan, P. Prospects and potential of poultry manure. Asian J. Plant. Sci. 2010, 9, 172-182.

32. Nicholson, F.A.; Chambers, B.J.; Smith, K.A. Nutrient composition of poultry manures in England and Wales. Bioresour. Technol. 1996, 58, 279-284.

33. Amanullah, M.M.; Vaiyapuri, K.; Sathyamoorthi, K. Poultry manure to crops-A review. Agric. Rev. 2007, 28, 216-222.

34. Ravikumar, R.; Krishnamoorthy, K. Effect of recycling of organic wastes on plant growth and physical proper-ties of soil. In Annual Report of All Indian Coordinated Research Project for Improvement of Soil Physical Conditions to Increase Agricultural Production of Problem Soil; National Academy of Agricultural Sciences: Coimbatore, India, 1975; pp. 91-94.

35. Diacono, M.; Montemurro, F. Effectiveness of organic wastes as fertilizers and amendments in salt-affected soils. Agriculture 2015, 5, 221-230.

36. Mbagwu, J.S.C. Improving the productivity of a degraded ultisol in Nigeria using organic and inorganic amendments. Part 2: Changes in physical properties. Bioresour. Technol. 1992, 42, 167-175.

37. Agbede, T.; Ojeniyi, S.; Adeyemo, A. Effect of poultry manure on soil physical and chemical properties, growth and grain yield of sorghum in southwest. Nigeria. Am. Eurasian J. Sustain. Agric. 2008, 2, 72-77.

38. Acosta-Martinez, A.; Harmel, R.D. Soil microbial communities and enzyme activities under various poultry litter application rates. J. Environ. Qual. 2006, 35, 1309-1318.

39. Zhen, Z.; Liu, H.T.; Wang, N.; Guo, L.Y.; Meng, J.; Ding, N.; Wu, G.L.; Jiang, G.M. Effects of manure compost application on soil microbial community diversity and soil microenvironments in a temperate cropland in China. PLoS ONE 2014, 9, e108555.

40. Lu, J.; Sanchez, S.; Hofacre, C.; Maurer, J.J.; Harmon, B.G.; Lee, M.D. Evaluation of Broiler Litter with Reference to the Microbial Composition as Assessed by Using 16S rRNA and Functional Gene Markers. Appl. Environ. Microbiol. 2003, 69, 901-908. [PubMed]

41. Enticknap, J.J.; Nonogaki, H.; Place, A.R.; Hill, R.T. Microbial Diversity Associated with Odor Modification for Production of Fertilizers from Chicken Litter. Appl. Environ. Microbiol. 2006, 72, 4105-4114. [PubMed]

42. Wadud, S.; Michaelsen, A.; Gallagher, E.; Parcsi, G.; Zemb, O.; Stuetz, R.; Manefield, M. Bacterial and fungal community composition over time in chicken litter with high or low moisture content. Br. Poult. Sci. 2012, 53, 561-569. [CrossRef] [PubMed]

43. Kyakuwaire, M.; Olupot, G.; Amoding, A.; Nkedi-Kizza, P.; Ateenyi Basamba, T. How Safe is Chicken Litter for Land Application as an Organic Fertilizer?: A Review. Int. J. Environ. Res. Public Health 2019, 16, 3521. 
44. Carrera, L.M.; Buyer, J.S.; Vinyard, B.; Abdul-Baki, A.A.; Sikora, L.J.; Teasdale, J.R. Effects of cover crops, compost, and manure amendments on soil microbial community structure in tomato production systems. Appl. Soil Ecol. 2007, 37, 247-255.

45. McGrath, S.; Maguire, R.O.; Tracy, B.F.; Fike, J.H. Improving soil nutrition with poultry litter application in low-input forage systems. Agron. J. 2010, 102, 48-54.

46. Bolan, N.S.; Szogi, A.; Chuasavathi, T.; Seshadri, B.; Rothrock, M.; Panneerselvam, P. Uses and management of poultry litter. World Poult. Sci. J. 2010, 66, 673-698.

47. Smith, L.W.; Fries, G.F. Dehydrated poultry manure as a crude protein supplement for lactating cows. J. Dairy Sci. 1973, 56, 668-672.

48. Fontenot, J.P.; De Baca, R.C.; Glimp, H.A. Recycling Animal Wastes by Feeding to Enhance Environmental Quality. Prof. Anim. Sci. 1991, 7, 1-8.

49. Sharma, M.; Joshi, C.; Saxena, N. Mineral toxicity in livestock: A review. Indian J. Anim. Sci. 2005, 75, 753-764.

50. Turnell, J.R.; Faulkner, R.D.; Hinch, G.N. Recent advances in Australian broiler litter utilisation. World Poult. Sci. J. 2007, 63, 223-231.

51. Finstein, M.S.; Morris, M.L. Microbiology of municipal solid waste composting. Adv. Appl. Microbiol. 1975, 19, 113-151. [PubMed]

52. Chen, Z.; Jiang, X. Microbiological Safety of Chicken Litter or Chicken Litter-Based Organic Fertilizers: A Review. Agriculture 2014, 4, 1-29.

53. Ahmed, Z.A.; Hussin, H.; Rohaim, M.; Nasr, S. Efficacy of composting dead poultry and farm wastes infected with avian influenza virus H5N1. Am. Eurasian J. Agric. Environ. Sci. 2012, 12, 588-596.

54. Khalil, A.; Domeizel, M.; Prudent, P. Monitoring of green waste composting process based on redox potential. Bioresour. Technol. 2008, 99, 6037-6045. [CrossRef]

55. Willson, G.B. Combining raw materials for composting. BioCycle 1989, 30, 82-83.

56. Bueno, P.; Tapias, R.; Lopez, F.; Diaz, M.J. Optimizing composting parameters for nitrogen conservation in composting. Bioresour. Technol. 2008, 99, 5069-5077.

57. Diaz, M.J.; Eugenio, M.E.; Jimenez, L.; Madejon, E.; Cabrera, F. Modelling vinasse/cotton waste ratio incubation for optimum composting. Chem. Engl. J. 2003, 93, 233-240.

58. Gray, K.; Sherman, K.; AJ, B. A Review of Composting-Part 1. Process Biochem. 1971, 6, 32-36.

59. Nakasaki, K.; Ohtaki, A. A simple numerical model for predicting organic matter decomposition in a fed-batch composting operation. J. Environ. Qual. 2002, 31, 997-1003. [CrossRef]

60. Eiland, F.; Klamer, M.; Lind, A.M.; Leth, M.; Baath, E. Influence of initial C/N ratio on chemical and microbial composition during long term composting of straw. Microbial Ecol. 2001, 41, 272-280. [CrossRef] [PubMed]

61. Ghosh, P.K.; Sarma, U.S.; Das Ravindranath, A.; Radhakrishnan, S.; Ghosh, P. A novel method for accelerated composting of coir pith. Energy Fuels 2007, 21, 822-827. [CrossRef]

62. Tuomela, M.; Vikman, M.; Hatakka, A.; Itavaara, M. Biodegradation of lignin in a compost environment: A review. Bioresour. Technol. 2000, 72, 169-183. [CrossRef]

63. Steiner, C.; Das, K.C.; Melear, N.; Lakly, D. Reducing nitrogen loss during poultry litter composting using biochar. J. Environ. Qual. 2010, 39, 1236-1242. [CrossRef] [PubMed]

64. Hachicha, S.; Chtourou, M.; Medhioub, K.; Ammar, E. Compost of poultry manure and olive mill wastes as an alternative fertilizer. Agron. Sustain. Dev. 2006, 26, 135-142. [CrossRef]

65. Ch'ng, H.Y.; Ahmed, O.H.; Kassim, S.; Ab Majid, N.M. Co-composting of pineapple leaves and chicken manure slurry. Int. J. Recycl. Org. Waste Agric. 2013, 2, 1-8. [CrossRef]

66. Sakthivadivu, R.; Sivakumar, K.; Kumar, V.R.S.; Natarajan, A. Chemical changes during composting of poultry waste with coirpith waste and sugarcane top. Inter. J. Sci. Environ. Technol. 2015, 4, 40-49.

67. Thomas, G.V.; Palaniswami, C.; Prabhu, S.R.; Gopal, M.; Gupta, A. Co-composting of coconut coir pith with solid poultry manure. Curr. Sci. 2013, 104, 245-250.

68. Libby, D.A.; Schaible, P.J. Observations on growth responses to antibiotics and arsonic acids in poultry feeds. Science 1995, 121, 733-734. [CrossRef]

69. Stokstad, E.L.; Jukes, T.H. Studies of the growth-promoting effect of antibiotics in chicks on a purified diet. Antibiot. Annu. 1958, 6, 998-1002.

70. Waibel, P.E.; Abbott, O.; Baumann, C.; Bird, H. Disappearance of the growth response of chicks to dietary antibiotics in an "old" environment. Poult. Sci. 1954, 33, 1141-1146. [CrossRef] 
71. Moore, P.; Evenson, A.; Luckey, T.; McCoy, E.; Elvehjem, C.; Hart, E. Use of sulfasuxidine, streptothricin, and streptomycin in nutritional studies with the chick. J. Biol. Chem. 1946, 165, 437-441.

72. Phillips, I.; Casewell, M.; Cox, T.; De Groot, B.; Friis, C.; Jones, R.; Nightingale, C.; Preston, R.; Waddell, J. Does the use of antibiotics in food animals pose a risk to human health? A critical review of published data. J. Antimicrob. Chemother. 2004, 53, 28-52. [CrossRef]

73. Graham, J.P.; Boland, J.J.; Silbergeld, E. Growth promoting antibiotics in food animal production: An economic analysis. Public Health Rep. 2007, 122, 79-87. [CrossRef] [PubMed]

74. Van Boeckel, T.P.; Brower, C.; Gilbert, M.; Grenfell, B.T.; Levin, S.A.; Robinson, T.P.; Teillant, A.; Laxminarayan, R. Global trends in antimicrobial use in food animals. Proc. Natl. Acad. Sci. USA 2015, 112, 5649-5654. [CrossRef] [PubMed]

75. Barros, R.; Vieira, S.L.; Favero, A.; Taschetto, D.; Mascarello, N.C.; Cemin, H.S. Reassessing flavophospholipol effects on broiler performance. Revista Brasileira Zootecnia 2012, 41, 2458-2462. [CrossRef]

76. Salmon, R.E.; Stevens, V.I. Effect of bambermycins (Flavomycin) in diets for growing turkeys. Poult. Sci. 1990, 69, 1133-1140. [CrossRef]

77. McDougald, L.R. Intestinal protozoa important to poultry. Poult. Sci. 1998, 77, 1156-1158. [CrossRef]

78. Elwinger, K.; Berndtson, E.; Engström, B.; Fossum, O.; Waldenstedt, L. Effect of antibiotic growth promoters and anticoccidials on growth of Clostridium perfringens in the caeca and on performance of broiler chickens. Acta Vet. Scand. 1998, 39, 433-441.

79. Hao, H.; Cheng, G.; Iqbal, Z.; Ai, X.; Hussain, H.I.; Huang, L.; Dai, M.; Wang, Y.; Liu, Z.; Yuan, Z. Benefits and risks of antimicrobial use in food-producing animals. Front. Microbiol. 2014, 5, 288. [CrossRef]

80. Koutoulis, K.C.; Kefalas, G.; Minos, E. Salinomycin toxicosis in broiler breeders and turkeys: Report of the first case. Am. J. Anim. Vet. Sci. 2013, 8, 190-196. [CrossRef]

81. Logan, N.B.; McKenzie, M.E.; Conway, D.P.; Chappel, L.R.; Hammet, N.C. Anticoccidial efficacy of semduramicin.: 2. Evaluation against field isolates including comparisons with salinomycin, maduramicin, and monensin in battery tests. Poult. Sci. 1993, 72, 2058-2063. [CrossRef] [PubMed]

82. Combs, G.; Romoser, G.; Shaffner, C. Nystatin (mycostatin) in rations for growing turkeys. Poult. Sci. 1958, 37, 896-898. [CrossRef]

83. Kruse, H.; Johansen, B.K.; Rorvik, L.M.; Schaller, G. The use of avoparcin as a growth promoter and the occurrence of vancomycin-resistant Enterococcus species in Norwegian poultry and swine production. Microb. Drug Resist. 1999, 5, 135-139. [CrossRef] [PubMed]

84. Bager, F.; Madsen, M.; Christensen, J.; Aarestrup, F.M. Avoparcin used as a growth promoter is associated with the occurrence of vancomycin-resistant Enterococcus faecium on Danish poultry and pig farms. Prev. Vet. Med. 1997, 31, 95-112. [CrossRef]

85. Pantosti, A.; Del Grosso, A.; Tagliabue, S.; Macri, A.; Caprioli, A. Decrease of vancomycin-resistant enterococci in poultry meat after avoparcin ban. Lancet 1999, 354, 741-742. [CrossRef]

86. Kieke, A.L.; Borchardt, M.A.; Kieke, B.A.; Spencer, S.K.; Vandermause, M.F.; Smith, K.E.; Jawahir, S.L.; Group MES. Use of streptogramin growth promoters in poultry and isolation of streptogramin-resistant Enterococcus faecium from humans. J. Infect. Dis. 2006, 194, 1200-1208. [CrossRef]

87. Marshall, B.M.; Levy, S.B. Food animals and antimicrobials: Impacts on human health. Clin. Microbiol. Rev. 2011, 24, 718-733. [CrossRef]

88. Wellenreiter, R.H.; Mowrey, D.H.; Stobbs, L.A.; d'Assonville, J.A. Effects of avilamycin on performance of broiler chickens. Vet. Ther. 2000, 1, 118-124.

89. Castillo, M.; Martin-Orue, S.M.; Roca, M.; Manzanilla, E.G.; Badiola, I.; Perez, J.F.; Gasa, J. The response of gastrointestinal microbiota to avilamycin, butyrate, and plant extracts in early-weaned pigs. J. Anim. Sci. 2006, 84, 2725-2734. [CrossRef] [PubMed]

90. Dumonceaux, T.J.; Hill, J.E.; Hemmingsen, S.M.; Van Kessel, A.G. Characterization of intestinal microbiota and response to dietary virginiamycin supplementation in the broiler chicken. Appl. Environ. Microbiol. 2006, 72, 2815-2823. [CrossRef] [PubMed]

91. Pedroso, A.A.; Menten, J.F.M.; Lambais, M.R.; Racanicci, A.M.C.; Longo, F.A.; Sorbara, J.O.B. Intestinal bacterial community and growth performance of chickens fed diets containing antibiotics. Poult. Sci. 2006, 85, 747-752. [CrossRef] [PubMed] 
92. Shim, Y.; Shinde, P.; Choi, J.; Kim, J.; Seo, D.; Pak, J.; Chae, B.; Kwon, I. Evaluation of multi-microbial probiotics produced by submerged liquid and solid substrate fermentation methods in broilers. Asian-Aust. J. Anim. Sci. 2010, 23, 521-529. [CrossRef]

93. Islam, K.M.S.; Klein, U.; Burch, D.G.S. The activity and compatibility of the antibiotic tiamulin with other drugs in poultry medicine-A review. Poult. Sci. 2009, 88, 2353-2359. [CrossRef]

94. Chopra, I.; Roberts, M. Tetracycline antibiotics: Mode of action, applications, molecular biology, and epidemiology of bacterial resistance. Microbiol. Mol. Biol. Rev. 2001, 65, 232-260. [CrossRef]

95. Chopra, I.; Hawkey, P.; Hinton, M. Tetracyclines, molecular and clinical aspects. J. Antimicrob. Chemoth. 1992, 29, 245-277. [CrossRef]

96. Schnappinger, D.; Hillen, W. Tetracyclines: Antibiotic action, uptake, and resistance mechanisms. Arch. Microbiol. 1996, 165, 359-369. [CrossRef]

97. Mingeot-Leclercq, M.-P.; Glupczynski, Y.; Tulkens, P.M. Aminoglycosides: Activity and resistance. Antimicrob. Agents Chemother. 1999, 43, 727-737. [CrossRef]

98. Udumula, V.; Ham, Y.H.; Fosso, M.Y.; Chan, K.Y.; Rai, R.; Zhang, J.; Li, J.; Chang, C.-W. Investigation of antibacterial mode of action for traditional and amphiphilic aminoglycosides. Bioorgan. Med. Chem. Lett. 2013, 23, 1671-1675. [CrossRef]

99. Javed, V.; Saleemi, M.; Khan, M.; Khan, A.; Javed, I. Pathological effects of gentamicin in growing broilers. In Proceedings of the 15th Congress of FAVA-OIE Joint Symposium on Emerging Diseases, Bangkok, Thailand, 27-30 October 2008; pp. 17-18.

100. Morar, M.; Bhullar, K.; Hughes, D.W.; Junop, M.; Wright, G.D. Structure and mechanism of the lincosamide antibiotic adenylyltransferase LinB. Structure 2009, 17, 1649-1659. [CrossRef]

101. Tenson, T.; Lovmar, M.; Ehrenberg, M. The mechanism of action of macrolides, lincosamides and streptogramin B reveals the nascent peptide exit path in the ribosome. J. Mol. Biol. 2003, 330, 1005-1014. [CrossRef]

102. Van Bambeke, F.; Virgincar, N.; MacGowan, A. Glycopeptides (Dalbavancin, Oritavancin, Teicoplanin, Telavancin, Vancomycin). In Antimicrobial Therapy and Vaccines. Vol. II: Antimicrobial Agents 181-200; ESun Technologies: Pittsburgh, PA, USA, 2009.

103. Zavascki, A.P.; Goldani, L.Z.; Li, J.; Nation, R.L. Polymyxin B for the treatment of multidrug-resistant pathogens: A critical review. J. Antimicrob. Chemother. 2007, 60, 1206-1215. [CrossRef] [PubMed]

104. Hawkey, P.M. Mechanisms of quinolone action and microbial response. J. Antimicrob. Chemother. 2003, 51, 29-35. [CrossRef] [PubMed]

105. Hooper, D.C. Mechanisms of action of antimicrobials: Focus on fluoroquinolones. Clin. Infect. Dis. 2001, 32, S9-S15. [CrossRef] [PubMed]

106. Agunos, A.; Carson, C.; Léger, D. Antimicrobial therapy of selected diseases in turkeys, laying hens, and minor poultry species in Canada. Can. Vet. J. 2013, 54, 1041-1052.

107. Mubito, E.B.; Shahada, F.; Kimanya, M.E.; Buza, J.J. Sulfonamide residues in commercial layer chicken eggs in Dar-es-Salaam, Tanzania. Am. J. Res. Commun. 2014, 2, 124-132.

108. Cheong, C.; Parvaneh, H.; Selamat, J.; Rashedi, M.; Fitry, I. Sulfonamides determination in chicken meat products from Malaysia. Int. Food. Res. J. 2010, 17, 885-892.

109. Horton-Smith, C.; Long, P. Effect of sulfonamide medication on the life cycle of Eimeria meleagrimitis in turkeys. Exp. Parasitol. 1961, 11, 93-101. [CrossRef]

110. Ungureanu, V. Macrolides, lincosamides, streptogramines (MLS): Mechanisms of action and resistance. Bacteriol. Virusol. Parazitol. Epidemiol. 2010, 55, 131-138.

111. Shryock, T.; Mortensen, J.; Baumholtz, M. The effects of macrolides on the expression of bacterial virulence mechanisms. J. Antimicrob. Chemother. 1998, 41, 505-512. [CrossRef]

112. Nakajima, Y. Mechanisms of bacterial resistance to macrolide antibiotics. J. Infect. Chemoth. 1999, 5, 61-74. [CrossRef] [PubMed]

113. Mubito, E.P.; Shahada, F.; Kimanya, M.E.; Buza, J.J. Antimicrobial use in the poultry industry in Dar-es-Salaam, Tanzania and public health implications. Am. J. Res. Commun. 2014, 2, 51-63.

114. Vazquez, D. Studies on the mode of action of the streptogramin antibiotics. Microbiology 1966, 42, 93-106. [CrossRef] [PubMed]

115. Johnston, N.J.; Mukhtar, T.A.; Wright, G.D. Streptogramin antibiotics: Mode of action and resistance. Curr. Drug Targets 2002, 3, 335-344. [CrossRef] 
116. Butaye, P.; Devriese, L.A.; Haesebrouck, F. Antimicrobial growth promoters used in animal feed: Effects of less well known antibiotics on gram-positive bacteria. Clin. Microbiol. Rev. 2003, 16, 175-188. [CrossRef]

117. Laue, H.; Weiss, L.; Bernardi, A.; Hawser, S.; Lociuro, S.; Islam, K. In vitro activity of the novel diaminopyrimidine, iclaprim, in combination with folate inhibitors and other antimicrobials with different mechanisms of action. J. Antimicrob. Chemoth. 2007, 60, 1391-1394. [CrossRef]

118. Maasjost, J.; Mühldorfer, K.; de Jäckel, S.C.; Hafez, H. Antimicrobial susceptibility patterns of enterococcus faecalis and enterococcus faecium isolated from poultry flocks in germany. Avian Dis. 2015, 59, 143-148. [CrossRef]

119. Williamson, R.; Collatz, E.; Gutmann, L. Mechanisms of action of beta-lactam antibiotics and mechanisms of non-enzymatic resistance. Presse Medicale 1986, 15, 2282-2289.

120. Tipper, D.J. Mode of action of $\beta$-lactam antibiotics. Pharmacol. Ther. 1985, 27, 1-35. [CrossRef]

121. Dierikx, C.M. Beta-Lactamases in Enterobacteriaceae in Broilers. Ph.D. Thesis, Utrecht University, Utrecht, The Netherlands, 2013.

122. Vinay Kant, P.S.; Verma, P.K.; Bais, I.; Parmar, M.S.; Gopal, A.; Gupta, V. Anticoccidial drugs used in the poultry: An overview. Sci. Inter. 2013, 1, 261-265. [CrossRef]

123. Leme, I.L.; Ferreira, A.J.P.; Bottino, J.A.; Pignatari, A.C.C. Glycopeptides susceptibility among enterococci isolated from a poultry farm in São Paulo, Brazil (1996/1997). Braz. J. Microbiol. 2000, 31, 53-57. [CrossRef]

124. Kyriakis, S.C. The effect of avilamycin in the control of stress-induced post-weaning diarrhoea in piglets. J. Vet. Pharmacol. Ther. 1989, 12, 296-301. [CrossRef] [PubMed]

125. La-ongkhum, O.; Pungsungvorn, N.; Amornthewaphat, N.; Nitisinprasert, S. Effect of the antibiotic avilamycin on the structure of the microbial community in the jejunal intestinal tract of broiler chickens. Poult. Sci. 2011, 90, 1532-1538. [CrossRef] [PubMed]

126. Egger, H.; Reinshagen, H. New pleuromutilin derivatives with enhanced antimicrobial activity. II. Structure-activity correlations. J. Antibiot. 1976, 29, 923-927. [CrossRef]

127. Tenover, F.C. Mechanisms of antimicrobial resistance in bacteria. Am. J. Med. 2006, 119, S3-S10. [CrossRef] [PubMed]

128. Van Leeuwen, F.X.R. Toxicological Evaluation of Certain Veterinary Drug Residues in Food; The Joint FAOWHO Expert Committee on Food Additives: Rome, Italy, 1991.

129. Lewicki, J.; Reeves, P.T.; Swan, G.E. Residue Evaluation of Certain Veterinary Drugs. In Proceedings of the 70th Meeting of the Joint FAOWHO Expert Committee on Food Additives, Geneva, Switzerland, 21-29 October 2008; pp. 243-279.

130. Goetting, V.; Lee, K.A.; Tell, L.A. Pharmacokinetics of Veterinary Drugs in Laying Hens and Residues in Eggs: A Review of the Literature. J. Vet. Pharmacol. Ther. 2011, 34, 521-556. [CrossRef] [PubMed]

131. Muaz, K.; Riaz, M.; Akhtar, S.; Park, S.; Ismail, A. Antibiotic Residues in Chicken Meat: Global Prevalence, Threats, and Decontamination Strategies: A Review. J. Food Prot. 2018, 81, 619-627. [CrossRef]

132. Aminov, R.I.; Mackie, R.I. Evolution and ecology of antibiotic resistance genes. FEMS Microbiol. Lett. 2007, 271, 147-161. [CrossRef]

133. Thiele-Bruhn, S.; Beck, I.C. Effects of sulfonamide and tetracycline antibiotics on soil microbial activity and microbial biomass. Chemosphere 2005, 59, 457-465. [CrossRef]

134. Kotzerke, A.; Sharma, S.; Schauss, K.; Heuer, H.; Thiele-Bruhn, S.; Smalla, K.; Wilke, B.-M.; Schloter, M. Alterations in soil microbial activity and $\mathrm{N}$-transformation processes due to sulfadiazine loads in pig-manure. Environ. Pollut. 2008, 153, 315-322. [CrossRef]

135. Ding, C.; He, J. Effect of antibiotics in the environment on microbial populations. Appl. Microbiol. Biotechnol. 2010, 87, 925-941. [CrossRef] [PubMed]

(C) 2020 by the authors. Licensee MDPI, Basel, Switzerland. This article is an open access article distributed under the terms and conditions of the Creative Commons Attribution (CC BY) license (http://creativecommons.org/licenses/by/4.0/). 